К. Х. Зеленський, В. М. Ігнатенко, О. А. Стенін

\title{
СТРУКТУРНА ВЛАСТИВІСТЬ ОПТИМАЛЬНИХ ЗА ВИТРАТАМИ ПАЛИВА ПРОЦЕСІВ УПРАВЛІННЯ В ДИНАМІЧНИХ СИСТЕМАХ
}

\section{Вступ}

У зв'язку із тенденцією до інтенсифікації процесів все частіше і частіше виникає потреба оптимального у визначеному сенсі управління об'єктами. Застосування лінійних законів управління для ряду об'єктів виявилося недостатньо ефективним через обмеженість керуючих впливів, великих швидкостей зміни координат об'єкту порівняно із великим запізненням в реакції системи на керуючий вплив.

У низці випадків неправильно або неточно сформований на початку процесу управління керуючий вплив призводить до неможливості у подальшому наявними засобами скорегувати недопустимий з тих чи інших причин розвиток процесу. У цьому випадку виникає задача захисту об'єкту управління від попадання у недопустимий стан як при ручному управлінні, так і при несправності системи автоматичного управління. Ці обставини у низці випадків змушують навмисно уповільнювати процеси управління.

Оптимізація процесів класичними методами i, зокрема, побудова оптимальних за швидкодією систем, незважаючи на розвинену теорію, наштовхується на труднощі апаратурної реалізації систем управління (використання в системі управління обчислювальних пристроїв для розв'язання крайових задач за принципом максимуму, для відтворення поверхні або гіперповерхні перемикання, для вирішення трансцендентних рівнянь і т. п.).

Але прискорення процесів управління може бути досягнуто й іншим шляхом, а саме, за допомогою методу прогнозування. Характерна особливість цього методу полягає у послідовному визначенні кінцевого результату впливу обраного у даний момент управління. Метод прогнозування вперше був використаний в роботі [1], розвинений надалі у роботі[2], для оптимального управління об'єктами другого порядку 3 нестаціонарними лініями перемикання. Характерним для цих робіт $є$ прогнозування на обчислювальних машинах 3 повторенням рішення сукупності майбутніх оптимальних траєкторій об'єкту із відокремлення із них тієї траєкторії, яка відповідає заданому кінцевому положенню об'єкта, а також використання логіки, розрахованої не більше ніж на одне перемикання керуючого впливу.

В [4] метод прогнозування використовувався для визначення управляючого впливу шляхом вирішення у прискореному масштабі часу спільно рівняння динаміки

(c) К. Х. Зеленський, В. М. Ігнатенко, О. А. Стенін 
об'єкта і варіаційного рівняння Ейлера для нього. При цьому із сукупності інтегральних кривих відбиралася та, яка відповідала бажаному кінцевому стану об'єкта.

Особливості застосування методу прогнозування в згаданих роботах не дозволяють поширити їх на об'єкти вище другого порядку і на об'єкти, що мають додаткові обмеження на координати. Але є можливість зняти зазначені обмеження принаймні для деяких класів об'єктів.

Крім задач оптимального управління метод прогнозування може бути ефективно поширений також і на низку інших задач, де прогнозування дозволяє значно поліпшити управління.

Мета цієї роботи - показати можливості та перспективи методу прогнозування стосовно задач управління.

\section{Постановка задачі оптимального за витратою палива управління}

Розглядається задача оптимального керування динамічними системами на часовому інтервалі, коли в якості критерію, що оцінює закон управління, виступають функціонали:

$$
I_{1}(u)=\int_{0}^{T_{k}} \sum_{k=1}^{r}\left|U_{k}(t)\right| d t,
$$

де $T_{k}=$ const $>0$, та

$$
I_{2}(u)=\int_{0}^{T_{k}}\left[\sum_{k=1}^{r}\left|U_{k}(t)\right|+K\right] d t,
$$

де $T_{k}-$ не заданий додатни й часовий інтервал керування, $u(t)-$ керуючий вплив на об'єкт керування, який має такі обмеження:

$$
U_{k}(t) \mid \leq U_{k, \max } \quad(k=\text { overline } 1, r),
$$

де $U_{k, \max }-$ максимальне значення керуючого впливу; $\left[0, T_{k}\right]-$ інтервал керування заданого об'єкта, коли $T_{k}$ - термінальне значення часу, тобто $t \in\left[0, T_{k}\right] ; K-$ вагова константа, яка враховує у значенні функціонала часовий інтервал керування об'єктом.

Фізична сутність даних критеріїв полягає в тому, що (1) оцінює чисту витрату палива, що використовується робочим тілом під час переходу із одного сталого стану в інший, а критерій (2) є по своїй природі комбінованим (компромісним), що враховує окрім витрат палива із вагою, що дорівнює $K, \mathrm{i}$ тривалість керування, інакше кажучи, процес керування згідно (2) є оптимальним як за витратою палива, так із вагою $K$ і за швидкодією.

Ці задачі оптимального керування сформовані і детально розглянуті в цілому ряді фундаментальних робіт по оптимізації, зокрема в [5]. Окрім цього в даній задачі існують обмеження у вигляді рівнянь зв'язків, що є диференційними 
рівняннями, які описують рух об’єкта керування в просторі фізичних координат і є по суті математичною моделлю об'єкта керування.

Розглядається клас лінійних динамічних систем, які описуються системою звичайних диференційних рівнянь зі сталими коефіцієнтами

$$
\frac{d x_{i}}{d t}=\sum_{j=1}^{n} a_{i j} x_{j}+\sum_{k=1}^{r} b_{i k} u_{k} \quad(i=\overline{1, n}),
$$

Система рівнянь (4) у векторній формі подається у такому вигляді:

$$
x=A x+B u
$$

де $x$-- $n$-вимірний вектор координат стану динамічної системи; $u=\left[u_{1}, u_{2}, \ldots, u_{r}\right]-$ $r$-вимірний вектор керування; $A$ - матриця розмірності $n \times n$ коефіцієнтів диференційного рівняння (5); $B$ - матриця розмірності $n \times r$ коефіцієнтів (5) при керуючому впливі.

У подальшому обмежуємося випадком, коли матриця $A$ має тільки діагональні і наддіагональні елементи, а матриця $B \in$ матриця-стовпець із одним ненульовим елементом, тобто розглядається система керування із сталими параметрами.

Такі введені обмеження на характер математичної моделі відповідають певному класу об'єктів керування, що структурно подаються у вигляді послідовного з'єднання динамічних ланок першого порядку.

Таким чином, маючи введені критерії оптимізації і обмеження у вигляді математичної моделі, можна сформулювати задачу синтезу (побудови) оптимальної системи керування за мінімальної витрати палива, а саме: необхідно знайти закони зміни керуючих впливів, які обмежені за величиною і забезпечують перехід відповідної динамічної системи із довільного початкового стану у заданий термінальний (кінцевий) стан при мінімальних витратах палива і заздалегідь не заданому часовому інтервалі керування.

\section{Метод прогнозованого управління}

Сутність методу управління із прогнозуванням полягає утому, що управляючий вплив формується на грунті результатів передбачення майбутньої поведінки об'єкту управління.

Залежно від оцінки розбіжності (різності) отриманого термінального прогногзованого стану системи (за умовами відповідно обраного оптимального управління) від заданого кінцевого стану , визначається управління системою у поточний момент часу. Тобто прогнозування вимагає знання математичного опису динаміки об'єкту та його поточного стану, а зіншого боку - розв'язання задачі про кінцевий стан об'єкту за певного управляючого впливу.

При реалізації оптимальних за витратою палива процесів управління 3 прогнозуючими пристроями важливо бути впевненим, що вони дійсно забезпечують мінімум відповідному критерію якості виду (1) або (2). 
Використовуючи принцип максимуму Л.С. Понтрягіна [6], можна показати, що це дійсно так, принаймні у тих випадках, коли заданий термінальний стан системи є рівноважним. Для цього достатньо довести, що оптимальне управління структурно складається 3 послідовних, відповідним чином сформованих, оптимальних за витратою палива управлінь для укороченої системи.

Вважається, що траєкторія $\bar{x}(t)$ і відповідне їй управління $u(t) \quad(0 \leq t \leq T$ послідовно оптимальні, якщо існує таке $\tau(0 \leq \tau \leq T$, що на інтервалах $(0, \tau) \mathrm{i}$ $(\tau, T)$ управління $u(t)$ збігається із оптимальним керуванням для системи, порядок якої на одиницю менше, ніж порядок вихідної системи. Необхідно показати, що побудовані відповідним чином послідовно оптимальні за витратою палива траєкторії усюди на інтервалі $(0, T)$ задовольняють принципу максимуму.

Розглядаються лінійні динамічні системи, які структурно подаються у вигляді послідовного з'єднання типових ланок автоматичного регулювання першого порядку та описуються системою диференціальних рівнянь виду:

$$
\begin{aligned}
\frac{d x_{n}}{d t} & =a_{n n} x_{n}+b_{n} u,|u| \leq 1, \\
\dddot{d x_{1}} & \cdots \cdots \cdots \\
d t & =a_{11} x_{1}+a_{12} x_{2},
\end{aligned}
$$

а укорочена на порядок система -- рівняннями виду

$$
\begin{aligned}
\frac{d x_{n}}{d t} & =a_{n n} x_{n}+b_{n} u,|u| \leq 1, \\
\dddot{d x_{2}} & \cdots \cdots \cdots \\
d t & =a_{22} x_{2}+a_{23} x_{3} .
\end{aligned}
$$

Припускається, що для систем (6) і (7) виконуються умови знакосталості.

Нехай існує допустиме управління, що переводить систему (6) із деякого початкового стану $x\left(t_{0}\right)=x_{0}$ за фіксований час $\tau$ в такий стан, що будь-яка вибрана координата $x_{i} \quad(1 \leq i \leq n)$ приймає екстремальне (максимальне або мінімальне) значення, і нехай при такому управлінні система (6) в момент $t=\tau$ міститься в деякій точці $x^{T}(\tau)=\left[x_{n}(\tau), \ldots, x_{1}(\tau)\right]$ фазового простору.

Нехай існує таке допустиме управління, що переводить при мінімумі витрат палива вкорочений систему (1) із точки $\bar{x}(\tau)$ у деяку точку $[\widetilde{x}]^{T}(\tau)=\left[\widetilde{x}_{n}(\tau), \ldots, \widetilde{x}_{2}(\tau)\right]$ $(n-1)$-вимірного фазового простору, і нехай цього руху системи (7) відповідає зміна координати $x_{1}$ від значення $x_{1}(\tau)$ до значення $x_{1}^{*}(\tau)$.

Таким чином, побудовано рух системи із точки $x_{0}$ у точку $x^{*}$, відповідну допустимому управлінню. Нехай $T$-- час цього руху, а $x^{*}(t)$ i $u^{*}(t)$ - відповідні йому траєкторія і управління. Рух такого типу будемо називати рухом по типу "розгін-відключення-гальмування". Інакше кажучи, рух системи iз $x_{0}$ у точку $x^{*}$ 
здійснюється за принципом "розгін-відключення-гальмування", якщо знайдеться такий момент $\tau(0 \leq \tau \leq T)$, коли:

1) на відрізку $(0, \tau)$ управління $u^{*}(t)$ максимізує (або мінімізує) одну із координат системи (1);

2) на відрізку $(\tau, T)$ управління $u^{*}(t)$ виводить скорочену на порядок систему (2) при мінімумі витрат палива з точки $x^{T}(\tau)=\left[\widetilde{x}_{n}(\tau), \ldots, \widetilde{x}_{2}(\tau)\right]$ у точку $\left[x^{*}\right]^{T}(\tau)=\left[x_{n}^{*}(\tau), \ldots, x_{2}^{*}(\tau)\right]$.

Виявляється, якщо $\tilde{x}$ відповідає рівноважному стану системи, управління $u^{*}(t)$ і траєкторія $\bar{x}^{*}(t)$ послідовно оптимальні i, при цьому, вони задовольняють принцип максимуму, що стверджується наступною теоремою.

Теорема. Нехай рух системи (6) у рівноважний стан здійснюється за принципом “розгін-відключення-гальмування". Тоді траєкторія $\bar{x}^{*}$ такого руху i відповідне йому управління $u^{*}(t)$ :

а) послідовно оптимальні;

б) на всьому відрізку $(0, T)$ управління $u^{*}(t)$ задовольняє принцип максимуму для повної системи (1) у сенсі оптимальності за витратою палива.

Доведення цієї теореми безпосередньо випливає із двох таких лем:

Лемма 1. Оптимальне управління $u^{*}(t)(0 \leq t \leq T)$, що забезпечує за фіксований час $\tau$ екстремальне значення однієї з координат системи (6), в той же час забезпечує екстремальні значення всім іншим координатам цієї системи, причому це управління екстремальне і на інтервалі $(0, \tau)$ не змінює свого знаку.

Дійсно, позначимо $u(t)=x_{0}(t)$. Оскільки похідні від правої частини системи рівнянь додатні (права частина системи рівнянь (6) є монотонна), розглянемо рух координати $x_{i}$ до максимального значення. Нехай існує така траєкторія системи (6), що під час руху за якою величина $x_{k-1}(t)=x_{k-1}^{*}(t)$ за будь-якого $t \geq 0$ має значення, не менше ніж при русі за будь-якою іншою траєкторією $x^{* *}(t)$, тобто $x_{k-1}^{*}(t) \geq x_{k-1}^{* *}(t)$. У силу монотонності правої частини системи рівнянь координата $x_{k}(t)$ під час руху за першою траєкторією буде не менша за другу, тобто $x^{*}(t) \geq x^{* *}(t)$. Оскільки це припущення справджується при $k=1$, воно справедливе за будь-якого $k$. У цьому разі управління $u^{*}(t)=x_{0}(t)$ можна вибрати максимальним, тобто $u^{*}(t)=1$.

3 цієї леми відразу випливає послідовна оптимальність управління $u^{*}(t)$ i траєкторії $\bar{x}^{*}(t)$. Дійсно, відповідно до леми 1 на першій ділянці $(0, \tau)$ траєкторії управління оптимальні для системи (6) будь-якого порядку, в тому числі і для скороченою системи (7). 
На другій ділянці $(\tau, T)$ управління і траєкторія оптимальні для скороченої системи (7) із визначення руху за принципом "розгін-відключеннягальмування".

Лемма 2. Для того щоб управління $u(t)$ системи типу (6) $n$-го порядку $(n=1,2, \ldots)$, що переводить іï у рівноважний стан, задовольняло принцип максимуму (в сенсі оптимальності за витратою палива), необхідно і достатньо, щоб $u(t)$ набувало значення тільки із послідовності $\{ \pm 1,0, \pm 1\}$ і змінювало знак не більше $2 n-1$ разів.

Доведення. Необхідність випливає із теореми 1, [3].

Достатність. Покажемо, що якщо $\tau_{1}, \tau_{2}, \ldots, \tau_{n-1}$-- деякі моменти переключення, існує неперевна вектор-функція $\varphi(t)$, що відповідає системі

$$
d \varphi_{i}(t) / d t=-a_{i i} \varphi_{i}(t)-a_{i, i+1} \varphi_{i+1}(t), i=\overline{1, n-1}, d \varphi_{n}(t) / d t=-a_{n, n-1} \varphi_{n}(t)
$$

і умові

$$
u^{*}(t)=u_{m} \operatorname{sign} \varphi_{1}(t) \operatorname{sign} B,
$$

яка змінює знак на інтервалах між коренів системи. Далі використовуємо теорему 2, [3].

\section{Висновки}

Досліджено структурні властивості багатовимірних лінійних систем, оптимальних за витратами палива. Доведено теорему про існування оптимального на відрізку управління, що задоваольняє принцип максимуму. Показано, що система n-го порядку може бути зведена до системи (n-1)-го порядку із збережнням динамічних властивостей системи оптимального управління за критерієм мінімуму вират палива.

\section{Список використаних джерел}

1. Coales J. F. An on-off servo mechanism with predicted Change-over.//J. Coales, A. Noton/IEE, pt.2, v. 108, N.10 - July 1956.

2. Chesnat H. Predictive control system application.//Chesnat H., Sollecito W., Troutman P./Appl. fund Ind, N.10. - Jule 1961.

3. Игнатенко В. Н. О числе переключений в оптимальных по расходу топлива системах управления// В. Н. Игнатенко, А. А. Стенин/ Адаптивные системы автом. управления: Респ. Межвед. Научн.-техн. сб., 1983, Вып. 11. - С.42-46.

4. Табак Д. Оптимальное управление и математическое программирование//Д. Табак, Б. Куо, Наука-1975.

5. Атанс М. Оптимальное управление// М. Атанс, Р. Фалб/ Машиностроение, 1968.

6. Понтрягин Л.С. Математичская теория оптимальных процессов // Л.С.Понтрягин, В.Г.Болтянский, Р.В.Гамкрелидзе, Е.Ф.Мищенко/ Наука, Главная редакция физико-математической литературы, 1969. 